\title{
A beacon in the night: government certification of SMEs towards banks
}

\author{
José Martí Pellón *, Universidad Complutense de Madrid \\ Anita Quas, emlyon business school
}

SBE Post-print

\begin{abstract}
Policymakers around the world have created several schemes to support financially-constrained SMEs. However, whether these mechanisms improve the access to external sources of finance or on the contrary crowd out private players remains a relevant question. In this paper we study the effectiveness of a recent form of government support, called participative loan, in improving recipient SMEs' access to external financial debt. Relying on the literature about the certification effect, we develop hypotheses on the conditions under which the improvement is stronger. The empirical analysis is based on a sample of 488 Spanish SMEs that received participative loans from a Spanish government agency and a control group of 719 matched twins. We show that the former register significantly higher external financial debt $(+31.5 \%)$. The effect is stronger for smaller firms, or for those operating in hightechnology sectors, which suffer more acutely from information asymmetries, and negligible for firms that already received support from another government-supported institution. After ruling out alternative explanations, we interpret this result as a positive evidence of government certification of SMEs towards banks.

JEL classification: G21, G28, H81
\end{abstract}

Keywords: certification hypothesis, participative loans, long-term financing, government intervention, subsidized loans.

*Corresponding author: Phone: +34913942310 Email: jmartipe@ccee.ucm.es

\section{Acknowledgements}

We thank Joern Block, Massimo Colombo and Silvio Vismara and two anonymous referees for their constructive comments. We acknowledge financial assistance from the Spanish Ministry of Economics and Competitiveness (ECO2014-55674-R). 


\section{Introduction}

SMEs experience more difficulties in accessing external finance than bigger firms due to high information asymmetries and low value of collateral (Binks et al. 1992). As a result, they usually resort to internal finance to fund their investment projects, and frequently forgo their growth opportunities when internal finance is not enough (Carpenter and Petersen 2002a). Since SMEs strongly contribute to value added and employment, policymakers have designed a variety of schemes to directly allocate public funding to SMEs, with various levels of success. ${ }^{1}$ There is a fierce academic debate, with uncertain conclusions (e.g., see Czarnitzki and Delanote 2015; Zúñiga Vicente et al. 2014), about the additionality of R\&D subsidies with respect to private investments (for a recent example, see Karhunen and Huovari 2015). Equity-based forms of government support to SMEs, such as government-affiliated Venture Capital (hereafter VC) programs, show negligible (Bertoni and Tykvová 2015; Grilli and Murtinu 2014), or even negative (Alperovych et al. 2015) effects on several performance measures, while the (scarce) literature on debt-based government initiatives to support SMEs highlights their effectiveness (Decramer and Vanormelingen 2016; Huergo and Moreno 2014).

In this work, we focus on a recent form of government intervention, called participative loans (hereinafter PLs), which is a hybrid financial instrument. Like loans, PLs have pre-determined maturity and interest payments but, like equity, the lender benefits from variable payments that depend on the profits (if any) of the borrower. The interest of PLs for entrepreneurial finance (and for this special issue) lies in the important advantages they present when compared to other forms of government support. From the government's perspective, PLs allow a recovery of government money that is, obviously, greater than that of R\&D subsidies, but also greater than that of traditional loans because of the variable additional payment collected from successful firms, which may offset losses from unsuccessful ones. ${ }^{2}$ From the firm's perspective, the recipient SME faces lower interest payments before reaching the breakeven point with respect to loans and does not suffer from internal capital dilution that would emerge from the access to external equity. Despite these advantages, PLs have received virtually no attention from the entrepreneurial finance literature.

\footnotetext{
${ }^{1}$ Governments have also developed indirect forms of support to SMEs, such as tax incentives (e.g., Busom et al. 2014) or credit guarantees (e.g., Kuo et al. 2011), the discussion of which is however beyond the scope of this study.

${ }^{2}$ Additionally, with respect to governmental VC, government agencies awarding PLs do not need to negotiate the initial price, are not limited by the presence of exit opportunities (which are scarce in Europe) and do not participate in the boards of directors of target firms. This last difference limits the hands on approach of the government in the firms' businesses, which however seems to be of scarce value added (Alperovych et al. 2015).
} 
We fill this gap by analyzing whether the receipt of PLs improved award-receiving SMEs' access to external finance by mitigating the problems related to information asymmetries, namely adverse selection and moral hazard (Binks et al. 1992). We use the theoretical lenses of the certification hypothesis, proposed by Lerner (2002). The theory suggests that, in the absence of direct information on the quality of a firm, private investors may rely on the receipt of selective forms of public support from the government to identify high-quality firms. In particular, we study the certification effect of PLs towards commercial banks, which are the most important source of external finance for SMEs (Binks et al. 1992). In addition, since the extant literature suggests that several factors moderate the effectiveness of government intervention (Grilli and Murtinu 2015; Meuleman and De Maeseneire 2012), we also investigate under which conditions award-receiving SMEs benefit more from the certification effect of PLs.

This work is interesting for the entrepreneurial finance literature because it contributes to the discussion about the government's ability to tackle the funding gap affecting SMEs. In fact, a limited number of contributions directly assess the effect of direct public financial aid on the reduction of financial constraints in supported firms (Colombo et al. 2013), or on their ability to access external finance (Feldman and Kelley 2006; Guerini and Quas 2015; Lerner 1999; Meuleman and De Maeseneire 2012). These aspects deserve more attention, however, especially in the light of the fact that government support may crowd out, rather than encourage, external private investments (e.g., Leleux and Surlemont 2003). Moreover, the certification hypothesis was never tested for government loans (nor on PLs) despite the fact that loans are the most common form of public support for SMEs, at least in Europe (Infelise 2014).

Our empirical analysis is based on 488 SMEs receiving PLs from a Spanish institution (Empresa Nacional de Innovación - ENISA) funded by the Spanish Ministry of Industry and Tourism, ${ }^{3}$ over the period 2005-2010. Tracking the evolution of these firms and of a matched sample of firms that did not receive PLs, we find that the former have a significantly higher financial debt. After ruling out alternative explanations, we attribute this effect to government certification towards commercial banks, which improves SMEs' access to financial debt $(+31.5 \%)$. We also find a stronger effect in firms that are affected by higher information asymmetries (i.e., smaller, high-technology firms) and a negligible effect in firms that had already benefited from the support of other government agencies.

\footnotetext{
${ }^{3}$ Other governmental agencies outside Spain have used PLs and similar hybrid instruments to support SMEs. An example is the Boost'PME program of PLs granted by the French ISODEV agency (OECD, 2015).
} 
The rest of the paper is structured as follows. In Section 2 we describe the theoretical base and develop our hypotheses. In Section 3 we present the data and the methodology used to test our hypotheses. Results and robustness checks are shown in sections 4 and 5, respectively. Finally, in section 6 we discuss our findings and conclude our work.

\section{Theoretical base and hypotheses development}

\section{$2.1 \quad$ Information asymmetry and government certification to SMEs}

Information asymmetry arises when the information about a firm is not equally accessible to all firm's stakeholders (Stiglitz and Weiss 1981). When there is information asymmetry between SMEs' owners and finance providers, the latter have difficulties in discriminating between good and bad potential borrowers and adverse selection problems emerge. Commercial banks are particularly sensitive to this problem because of the limited screening skills they possess (Ueda 2004). After the loan is obtained, information asymmetry generates moral hazard problems by allowing entrepreneurs to misbehave (and gamble with the bank's money). Both of these issues create a debt gap, especially in the case of small firms that have low values of collateral and reputational capital (Binks et al. 1992).

Certification is one way in which policy makers can alleviate at least adverse selection problems in SMEs. Lerner (2002) argues that when the government allocates money to some selected (promising) firms, the receipt of public support can be used by private investors as an indication of the quality of the firm, and it is especially useful when direct information about it is missing. In other terms, the receipt of public support works as a stamp of approval of the government and certifies the value of the firm, lowering information asymmetries.

There is some empirical evidence supporting the certification hypothesis for different forms of government support. Lerner (1999) shows that US Small Business Innovation Research (SBIR) grants improve recipient SMEs' access to private VC. Feldman and Kelley $(2003,2006)$ find that firms receiving grants from the Advance Technology Program (ATP) are better able to raise additional funds from other sources. Meuleman and De Maeseneire (2012) show that R\&D grants exert a certification effect that increases the Belgian firms' likelihood of raising long-term debt and, especially for the youngest firms, external equity finance. Guerini and Quas (2015) find that high technology firms that receive government-affiliated VC finance in several European countries are three times more likely to receive private VC than their counterparts, also because of a certification effect.

The certification hypothesis has never been tested on government loans or on PLs. We argue that the intrinsic 
characteristics of PLs granted by a government agency make them a potentially effective mechanism of certification, especially towards commercial banks. A necessary condition for the certification to be effective is that the government support conveys positive information about the quality of the firm to private investors (Kleer 2010). We believe this is the case for PLs for several reasons. First, the lender usually requests the borrower to balance the amount of the PL with an additional predefined capital increase. Only shareholders that strongly believe in the future of their business will provide additional equity, while the others will self-select out of the process of applying for a PL. SMEs may also attempt to raise equity capital from external investors, but only firms able to prove their quality will be able to do so. Second, applicants go through a selection process in which information about the firm is screened by the government agency to identify high-quality borrowers. An important assumption at this stage is that government's assessments are independent, educated and technically sophisticated (Meuleman and De Maeseneire 2012). With respect to commercial banks, government agencies may have an advantage in the screening process because they centralize applications from a large number of applicants and may have a better understanding of the state of the art in specific technological fields. Moreover, the return on the investment in PLs includes a share of the profits of the borrower. ${ }^{4}$ Therefore, it is in the interest of the government (as lender) to be extremely selective in the award of loans because the higher the potential of the selected SMEs, the higher the additional payments received from successful firms.

PLs may also reduce potential moral hazard problems between firms and commercial banks for two reasons. First, unlike subsidies and government-affiliated VC, the firm must pay back the PL at maturity. This imposes selfdiscipline on the firm and a higher commitment to the project (Huergo et al. 2013), thus improving its reputational capital (Diamond 1991). Second, by requesting the borrower to undertake a capital increase, PLs offer further proof of shareholder commitment to the firm's investments and align the interests of shareholders and lenders (Tirole 2006).

Summing up, PLs may reduce adverse selection problems by certifying that award-receiving firms are of good quality, and reduce moral hazard problems by aligning the interests of shareholders and debt providers. Our first hypothesis follows:

\footnotetext{
${ }^{4}$ This clause may generate misalignment between the objectives of the governmental agency awarding PLs and those of commercial banks. The agency may be more inclined to finance high-risk high-return projects which would not be attractive for commercial banks. However, the provision of additional equity capital from firms' shareholders reduces this risk. First, the equity capital increases the company's liquidity, and therefore reduces its risk of default. Second, shareholders have more equity at stake, and therefore are less likely to take huge risks with their company.
} 
Hypothesis 1: SMEs receiving a PL from a government-supported institution will improve their ability to raise external debt, thanks to a certification effect.

\subsection{Factors moderating the certification effect}

Since PLs reduce the problems related to information asymmetries between SMEs and commercial banks, we predict that the receipt of PLs will be more beneficial for SMEs that are more strongly affected by these asymmetries. We focus on different firm-specific factors that can affect the effectiveness of certification: the size and age of the SMEs, the technological level of the industry in which they operate, and whether they were previously certified from similar (government agencies) or different (VC) organizations.

Size: Very small firms are typically more strongly affected by information opacity, as they are not well-known and often unable to provide audited financial statements (Bernanke et al. 1996). Because of the fixed costs associated with screening, contracting and monitoring loans, banks capture scale economies in dealing with large firms, while costs of information collection are exacerbated in relatively small businesses (Binks and Ennew 1996). Further, the use of collateral by these firms is limited by the low value of their assets (Binks et al. 1992). These circumstances increase the cost of debt for smaller borrowers, as proved by abundant empirical evidence (e.g., Magri 2009). The certification of PLs issued by the government lowers the cost of information collection that banks need to face. Hypothesis 2 follows:

Hypothesis 2: The certification effect of PLs granted by a government-supported institution is stronger for SMEs that were smaller at the time the loan was granted.

Age: Information asymmetries are particularly acute for recently-established firms, which lack a track record and are characterized by scarce visibility in the market (e.g., Hall 2002). Moreover, younger SMEs are affected by higher levels of uncertainty, related to both the product development and the commercialization phases (e.g., Sørensen and Stuart 2000). The receipt of government PLs should be particularly valuable for younger firms because it increases their visibility vis-a-vis commercial banks and their trustworthiness as borrowers. In fact, Meuleman and De Maeseneire (2012) find that the certification effect of R\&D subsidies towards external equity providers is stronger for younger firms. In our hypothesis 3 , we posit: 
Hypothesis 3: The certification effect of PLs granted by a government-supported institution is stronger for SMEs that were younger at the time the loan was granted.

Technological level: High-technology firms have technically sophisticated products, whose potential is especially difficult to evaluate for commercial banks (Lerner 2002). In addition, high-technology firms are particularly reluctant to share information about themselves, because of appropriability concerns (Teece 1986). This exacerbates information opacity around these firms. The use of collateral to moderate adverse selection from banks is hardly an option for high-technology SMEs because their assets are typically highly intangible (Carpenter and Petersen $2002 \mathrm{~b}$ ). Hypothesis 4 follows:

Hypothesis 4: The certification effect of PLs granted by a government-supported institution is stronger for SMEs operating in high-technology sectors.

Previous government certification: Pollock et al. (2010) show that multiple certifications by similar agents are redundant and have diminishing positive effects on investors' assessment of firm quality. Similarly, we expect the receipt of a PL to be less decisive for firms that have already received support from other government agencies, due to a redundancy of information. In fact, commercial banks may expect that the decision to award the SME with different forms of support is based on similar pieces of information and criteria. Hypothesis 5 follows:

Hypothesis 5: The certification effect of PLs granted by a government-supported institution is weaker for SMEs that already received support from government-affiliated institutions.

Previous VC certification: VC investors are known for certifying their portfolio firms at the time of the initial public offering (Lee and Wahal 2004). Commercial banks may be more willing to lend to firms whose value has been certified by the presence of a VC investor. However, there may be some redundancy of information between the receipt of $\mathrm{VC}$ and the receipt of PLs, even if the certifying agent is different in the two cases. In fact, Pollock et al. (2010) suggest that certifications from different actors partially mediate each other. We posit the following hypothesis:

Hypothesis 6: The certification effect of PLs granted by a government-supported institution is weaker for VC-backed SMEs.

\section{Methodology and data}




\subsection{The model}

Our empirical approach aims to analyze the effect of the receipt of PLs on SMEs' ability to raise external debt. We proxy this ability by the level of external debt raised by SMEs, represented by $\log D e b t_{i, t}$, which is computed as the logarithm of the book value of debt minus the outstanding amount of the PL if any. ${ }^{5}$

To test Hypothesis 1 , we regress $\log D e b t_{i, t}$ against a dummy variable $\left(P L_{i, t}\right)$ that is equal to 1 in the year in which a firm received its first PL and in all the following years, and 0 otherwise. We expect a positive coefficient for this variable. Hypotheses 2 to 6 predict that the treatment effect of the PL is moderated by firm-specific characteristics at the moment the loan was granted. We generate some time-invariant variables that measure those characteristics, and we then interact them with the dummy $P L_{i, t}$ to test our hypotheses 2 to 6 . Hypotheses 2 and 3 predict a stronger certification effect for firms that were smaller and younger at the time the loan was granted. We, therefore, generate the variables $\log$ TotalAssets ${ }^{\text {timeofPL }}{ }_{i}$ and $A g e^{\text {timeoffPL }}{ }_{i}$, respectively equal to the size (logarithm of total assets in thousand euros) and age of the firm in the year before the receipt of the first PL. We expect negative coefficients for the interactions of $P L_{i, t}$ with $\log$ TotalAssets ${ }^{\text {timeofP }}{ }_{i}$ and $A g e^{\text {timeofPL }}$. Hypothesis 4 predicts a stronger certification effect for firms operating in high-technology industries. We build the variable $H_{i g h T e c h}$ equal to 1 for firms operating in hightechnology industries. We anticipate a positive coefficient for the interaction of this variable with $P L_{i, t}$. To test hypotheses 5 and 6 on the non-additionality of PLs for firms that have already received support from a governmentaffiliated institution or from venture capitalists (VCs), we generate the variables PublicSupport ${ }^{\text {timeofPL }}{ }_{i}$ and $V C^{\text {timeofPL }}{ }_{i}$. These variables are respectively equal to 1 if the firm received support from the government or from VC investors up to the year prior to the receipt of the first PL. We anticipate negative coefficients for the interaction of $P L_{i, t}$ with PublicSupport ${ }^{\text {timeofPL }}{ }_{i}$ and $V C^{\text {timeofPL }}{ }_{i}$.

We include a wide set of control variables commonly used in the literature on capital structure. As the literature predicts a positive relationship between debt and size (Titman and Wessels 1988), we control for the size of the firm measured as the logarithm of total assets $\left(\right.$ logTotalAssets $\left._{i, t-1}\right)$. Total asset growth (TotalAssetGrowth Tht-I $_{\text {) }}$, measured as the difference between $\log _{\text {TotalAssets }}$, t-1 1 and $\log _{\text {TotalAsset }}$, t,-2 , is included to account for the growth

\footnotetext{
${ }^{5}$ There are two main reasons why we opted for an absolute measure of debt instead of a relative measure (such as debt on total assets). First, debt on total assets is by definition constrained to be between 0 and $100 \%$ and undervalues increases in debt when the equity amount is high. Second, all relative measures of debt (debt on total assets or debt on equity) also depend on equity. However, firms that received PLs are requested to increase their equity capital. Therefore, we believe that an absolute measure of debt is best suited for our study. Nevertheless, when we replace $\log D e b t_{i, t}$ with those relative measures the results, which are available from the authors upon request, are similar to those reported in section 4.
} 
opportunities of the firm (Michaelas et al. 1999). We control for the share of tangible assets on total assets (Tangibles $i, t-$ 1) because tangible assets can be pledged as collateral and are typically positively related to debt (Myers and Majluf 1984). Profitability also affects debt (see, e.g., Sogorb-Mira, 2005). We measure the firm's profitability (Profitability ${ }_{i, t-}$ 1) as the earnings before interest, taxes, depreciation and amortization over total assets. We control for the liquidity of

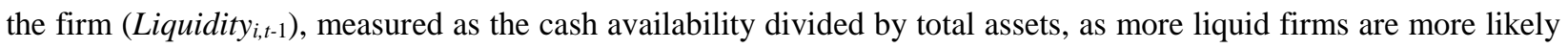
to raise debt (Hall 2002). Profitability $y_{i, t-1}$ and Liquidity $_{i, t-1}$ are winsorized at $1 \%$ to avoid outliers. We include the book value of equity in the previous year expressed in logarithm $\left(\log E q u i t y_{i, t-1}\right)$ because the debt capacity of a firm strongly depends on the level of equity (Tirole 2006). We control for the receipt of support from another government-affiliated institution or from VCs with two dummies. PublicSupport ${ }_{i, t-1}$ is the lag of a dummy equal to 1 in the year in which a firm received its first form of public support and in all the following years, and 0 otherwise. $V C_{i, t-l}$ is the lag of a dummy equal to 1 in the year in which a firm received its first VC round and in all the following years, and 0 otherwise. Lastly, in the model, we also include the firm age, measured in years since foundation $\left(\right.$ Age $\left._{i, t}\right)$, and year fixed effects.

The literature has found that most of the variability in the capital structure is driven by an unobserved timeinvariant effect (Lemmon et al. 2008). Therefore, fixed effects estimators are better suited than random effects ones when modeling debt. Accordingly, we resort to a fixed effects panel with robust standard errors to estimate our models.

\subsection{Research setting}

The study focuses on PLs granted to SMEs by Empresa Nacional de Innovación (hereinafter, ENISA) between 2005 and 2010. ENISA is a public institution supported by the Spanish Ministry of Industry, Energy, and Tourism. It was established in 1982 to commit money to high-technology firms, typically in the form of minority equity stakes, with the aim of bridging the equity gap left by private VC firms. As the Spanish VC market matured, ENISA gradually switched from equity to other financial instruments since 1996, when the government approved regulation of PLs. Since 2005 ENISA has considerably increased the number of PLs granted to SMEs.

ENISA provides PLs through three programs targeted at different categories of SMEs: high-technology (EBT program), high-growth (PYME program) and, since 2010, recently established SMEs (JOVENES program). The maturities of the PLs range from 4 to 9 years, and the repayment of the principal is delayed from 1 to up to 7 years. The explicit interest rate applied is floating and collateral is not required. ENISA's PLs are subordinated to any loans and only senior to pure equity, and are counted as equity for financial analysis purposes. To be eligible to obtain ENISA 
loans, the applicant must be an SME (according to the official EU definition) established in Spain and not belonging to the real estate or financial services sectors. The applicant must raise additional equity from existing shareholders or external investors, which ranges from $15 \%$ to $100 \%$ of the amount of the loan asked. Applicants must then go through a screening process, similar to a credit scoring model that takes into account the industry, location and stage of development of the firm, the personal characteristics of the team, the innovativeness of the business model and its competitive advantage, the technical and economic feasibility of the project and historical information about past loans granted. The evaluation process usually lasts from four to six weeks. The rate of success of applicants in obtaining funding is around $50 \%$. Firms receiving a PL are granted the amount required, albeit sometimes the requested amount is split into two rounds.

In this work we analyze PLs granted by ENISA through EBT, PYME and JOVENES programs between 2005 and 2010. As we show in Table 1, the population of these loans consists of 867 PLs awarded to 694 firms and amounting to 212 million Euros.

[Insert Table 1 here] 


\subsection{Data}

We created a sample of firms that received PLs (i.e., ENISA-backed firms) by merging several sources of data. ENISA provided the full list of loans granted by EBT, PYME and JOVENES programs in the period analyzed, which included the name of the firm, the program, the amount received, the date of the receipt of the loan, the maturity of the loan, the year of the first repayment of principal and the amounts repaid until 2013. This information allowed us to estimate the amount owed to ENISA by each firm in every year. We relied on the Webcapitalriesgo database to obtain information on the receipt of support from other government-affiliated institutions and VC firms. Webcapitalriesgo is a complete database of VC investments in Spain. It is the service provider to the Spanish Private Equity and Venture Capital Association (ASCRI) since 2000. The database also includes the information on the receipt of support, in the form of subsidized loans, from CDTI and ACCIO, Spanish government-affiliated institutions. ${ }^{6}$ Lastly, we extracted from Orbis information on the founding date, activity sector (NACE Rev. 2), geographical location and accounting data of the recipient firms up to 2013. We used the firms' NACE Rev. 2 codes to identify high-technology manufacturing and services using the Eurostat classification. ${ }^{7}$ We were able to find complete accounting data on 488 firms that received 673 loans from ENISA, representing $70 \%$ of the population. Table 2 reports the distribution of these firms across regions, industries and foundation periods, while Table 3 describes the characteristics of the firms at the time the first PL was granted.

[Insert Table 2 here]

[Insert Table 3 here]

In order to carry out a counterfactual analysis, we selected a control group of firms that did not receive a PL. The ideal control group firms would present similar characteristics to those of treated firms (Chemmanur et al. 2011; Croce et al. 2013; Puri and Zarutskie 2012) (i.e., ENISA-backed firms) before receiving the first PL in terms of their ability to raise external debt (Hypothesis 1), size (Hypothesis 2), age (Hypothesis 3), industry’s technological level

\footnotetext{
${ }^{6}$ CDTI (Centro para el Desarrollo Tecnológico e Industrial, dependent on the Spanish Ministry of Industry, Energy, and Tourism) and ACCIO (Agencia para la Competitividad de la Empresa, dependent on the regional government of Catalonia) are the two main providers of subsidized loans in Spain. Other regional governments started similar initiatives only recently, namely after 2010.

${ }^{7}$ High-technology manufacturing industries include NACE Rev. 2 codes 21 (manufacture of basic pharmaceutical products and pharmaceutical preparations), 26 (manufacture of computer, electronic and optical products) and 30.3 manufacture of air and spacecraft and related machinery (NACE Rev. 2 code 30.3). High technology knowledge-intensive services include NACE Rev. 2 codes 59 (motion picture, video and television programs production, sound recording and music publishing activities), 60 (programming and broadcasting activities), 61 (telecommunications), 62 (computer programming, consultancy and related activities), 63 (information service activities) and 72 (scientific research and development) (Eurostat 2015).
} 
(Hypothesis 4) and previous receipt of support from government-affiliated institutions (Hypothesis 5) and VC investors (Hypothesis 6). To identify the appropriate control group, we first used a random sampling to extract from Orbis 2,700 firms operating in Spain in the same industries (i.e., same NACE rev2 code) and geographical locations as ENISAbacked firms, founded in the same time span and with fewer than 250 employees in the period 2005-2010. We then merged this sample with the full list of firms that received subsidized loans granted by CDTI or ACCIO (209 firms) and VC financing (2,049 firms) according to Webcapitalriesgo, and for which accounting data was available in Orbis. ${ }^{8}$ After removing duplicates and missing data, the final number of nonENISA-backed firms is 4,697. Out of this sample, we use a propensity score matching to identify those firms that more closely resemble the 488 ENISA-backed firms before the receipt of the first PL. The matching variables include our proxy for the firms' ability to raise external debt $\left(\log \operatorname{Debt}_{i, t-1}\right)$, size $\left(\log \operatorname{TotalAsset}_{i, t-1}\right)$, age $\left(\right.$ Age $\left._{i, t}\right)$, industry's technological level $\left(\right.$ HighTech $\left._{i},\right)$, previous receipt of public support (PublicSupport $\left.t_{i, t-1}\right)$ and of $\mathrm{VC}$ investments $\left(V C_{i, t-1}\right)$, along with regional, year and industry dummies. In order to increase the precision of the matching algorithm, we perform exact matching on the age of the firm, whenever we have sufficient observations. We use the propensity score to choose, for every ENISA-backed firm in the year of the PL, the two most similar firm-year observations (nearest neighbors) in the group of firms that did not receive PLs. ${ }^{9}$ 719 firms that never received a PL were matched with the ENISA-backed firms for at least one year. They constitute our control group of "twins" of the 488 ENISA-backed firms. In our dataset, we keep observations of ENISA-backed firms and their matched twins for the four years before the matching and all the available years after the matching. Our final observation period covers the years 2001 to 2013. Because of the matching procedure, the distribution of ENISAbacked firms is not significantly different from that of control group firms across industries, regions and foundation periods $\left(\chi^{2}(11)=2.33, \chi^{2}(16)=8.38\right.$ and $\chi^{2}(3)=1.07$, respectively). The balancing of the matching with respect to the continuous matching variables was verified using T-tests. Variables for our final sample of ENISA-backed and control group firms are summarized in Table 4, while a correlation matrix is presented in Table 5.

[Insert Table 4 here]

${ }^{8}$ We incorporated in our sample the entire Webcapitalriesgo database in order to have a good coverage of the population of firms that received support from other government-affiliated institutions or from venture capitalists in our sample of nonENISA-backed firms, which is required to test hypotheses 5 and 6 . Although based on a smaller sample, results are similar if we rely purely on the Orbis database to select the control group.

${ }^{9}$ As robustness checks, we replicated our analysis using 1:1 and 1:3 matching algorithms, and without the exact matching on the age of the company. We obtain similar results to those reported in this work, which are available upon request. 
[Insert Table 5 here]

\section{Results}

In Table 6 we present the main results of our analysis. In column I we only include control variables. In column II we add the main independent variable $P L_{i, t}$. The positive sign of the variable is in accordance with our hypothesis 1 , indicating that firms receiving PLs have a significantly higher external financial debt (at the 5\% confidence level). The effect is also economically significant: firms that received a PL from ENISA register an increase of $31.5 \%\left(\mathrm{e}^{0.274}-\right.$ 1) in the financial debt obtained from external sources.

In column III we test hypothesis 2 by including $P L_{i, t} * \log$ TotalAssets $^{\text {timeofPL }}{ }_{i}$. The coefficient is negative and significant at the $1 \%$ level, as expected, supporting hypothesis 2 on a stronger increase in external financial debt for smaller firms. The effect is sizeable. With respect to the average ENISA-backed company, companies that were one standard deviation of $\log$ TotalAssets ${ }^{\text {timeofPL }}$ smaller in the year before the receipt of the first PL, registered an increase of external debt due to the PL that is $37.2 \%$ higher. The effect becomes negligible for companies with total assets higher than 6 million euros at the time the first PL was granted.

We do not find support for hypothesis 3: the coefficient of $P L_{i, t} * A g e^{t i m e o f P L}{ }_{i}$ is not significant in column IV, suggesting that firms that received a PL when they were younger do not benefit from a stronger certification effect than their peers.

In column $\mathrm{V}$ we find a positive coefficient (significant at the $1 \%$ level) for $P L_{i, t} * H i g h T e c h_{i}$. High-technology firms registered a greater external financial debt after the receipt of the PL, as predicted by hypothesis 4 (+84.6\%, i.e.,

$\left.\mathrm{e}^{0.536+0.078}-1\right)$. Moreover, the effect of PL on low-technology companies is negligible, as shown by the nonsignificant coefficient of $P L_{i, t \cdot}$.

The term $P L_{i, t} *$ PublicSupport ${ }^{\text {timeofP }}{ }_{i}$ has a negative and significant coefficient (at the $10 \%$ level) in Column VI, in line with Hypothesis 5. The sum of the coefficients of $P L_{i, t} * P u b l i c S u p p o r t{ }^{t i m e o f P} L_{i}$ and $P L_{i, t}$ is not different from 0 at standard significance levels, indicating that firms that already received support from government-affiliated institutions did not further benefit from the receipt of PLs in terms of ability to access external debt. 
Lastly, hypothesis 6 is not confirmed because $P L_{i, t} * V C^{\text {timeoffL }}{ }_{i}$ is not significant in column VII. VC-backed firms did not benefit less from the government's certification effect towards commercial banks. In Column VIII we include simultaneously all our independent variables. The results relative to that specification confirm our results and support hypotheses $1,2,4$ and 5.

[Insert Table 6 here]

\section{$5 \quad$ Robustness checks}

In what follows we challenge the assumption that our results are due to a certification effect by considering some alternative explanations.

Selection effects: Firms that received a PL may be different from the others because of some unobserved characteristics, such as quality, that also facilitate their access to external financial debt. If this is true then ENISAbacked firms may have higher external debt, not because of a treatment effect of the PL, but solely because of selection effects. This alternative explanation for our results, driven by the potential endogeneity of the PL, cannot be completely excluded with a matching procedure, which consists of picking twins of ENISA-backed firms based only on observable characteristics, and may create a bias in the estimated coefficients. In order to tackle the possible PL's endogenous treatment, we use the Vella and Verbeek (1999) variation of the Heckman (1979)'s two-step approach. In the first step, we estimate a Probit model with random effects to model firms' likelihood of receiving a PL, on the basis of all the variables included in our main model, together with regional and industry dummies. We also include ENISAavailability $_{i, t}$, representing the total amount of PLs granted by ENISA by year and province, expressed in million Euros (source: ENISA). The results of this first step are reported in Column I of Table 7. Firms are more likely to receive a PL if they are smaller, less profitable and with fewer tangible assets but growing and with more equity capital or VC (all these effects are significant at least at the 10\% level). Moreover, the positive and significant (at the 10\% level) coefficient of ENISAavailability E $_{i, t}$ shows that the probability of receiving a loan is higher in years and provinces with higher availability of PLs. We use the results of the Probit regression to compute an endogeneity correction term based on the Inverse Mills Ratio. In a second step, we add it in the external debt model (Column II). The correction term is not significant, indicating that the unobserved characteristics of firms that received PLs do not significantly 
affect their access to external debt. Moreover, the results relative to our hypotheses 1, 2, 4 and 5 are confirmed and coefficients are similar to those reported in column VIII of Table $6 .^{10}$

Increased tangibility: Bester (1985) shows that an increase in the value of collateral results in an easier access to commercial debt. ENISA-backed firms can use PLs to acquire tangible assets that can subsequently be pledged as collateral. In fact, in an unreported estimate, we find that the receipt of PLs significantly increases companies' tangible assets. ${ }^{11}$ Commercial banks may be more willing to lend money to ENISA-backed firms because they have higher tangibility (i.e., more collateral), and not because of a certification effect. In order to rule out the alternative hypothesis that the link between PL and access to bank loans is fully mediated by an increase of tangible assets, we augment our baseline model of external debt with the interaction between $P L_{i, t}$ and Tangibles Tht $_{i-1}$. In Column III of Table 7 we show a negative and significant coefficient for this interaction variable. The sum of coefficients of Tangibles $_{i, t-1}$ and $P L_{i, t} *$ Tangibles $_{i, t-1}$ is not significantly different from 0 at standard significance level, indicating that the debt of companies that received a PL is not sensitive to the tangibility of the company's assets. In other terms, the presence of collateral is not fundamental to access external debt for ENISA-backed companies. Moreover, the coefficient of $P L_{i, t}$ is still positive and significant: a certification effect is found even after controlling for the collateral effect of PLs (Colombo et al. 2013). Our hypotheses 1, 2, 4 and 5 are confirmed. The magnitude of the effect of PLs on external debt is however lower for companies with more tangibles, and becomes negligible when Tangibles Sit- $1_{\text {is }}$ higher than 0.5 , i.e. the $85^{\text {th }}$ percentile of the variable in our sample.

\section{[Insert Table 7 here]}

\section{Discussion and conclusion}

In this work we study the effectiveness of PLs granted by a government agency in improving recipient SMEs' access to external debt. PLs are hybrid financial instruments that share characteristics from traditional loans and equity. The lender is rewarded in two ways: a pre-determined interest rate, and a share of the firm's profits.

PLs are awarded selectively and often require the borrower to balance the amount of the PL with a predefined capital increase. High-quality SMEs are more likely to be able to raise the additional capital and successfully pass

\footnotetext{
${ }^{10}$ Results are also robust when using the 2SLS-IV approach (Angrist et al. 1996) as an alternative control for endogeneity.

${ }^{11}$ In particular, we estimate the impact of $P L_{i, t}$ on Tangibles $i, t$ using a fixed effects model and considering the same set of control variables used in the main analysis. Results are available upon request.
} 
through the government's screening process. Therefore, receipt of PLs can be seen by external investors, especially commercial banks, as an indication of the SMEs' quality. This is a necessary condition for a certification effect to be in place (Kleer 2010). The certification hypothesis (Lerner 2002) predicts that the receipt of selective forms of public support reduces information asymmetries around firms' quality and limits adverse selection problems, improving firms' access to external finance. While this hypothesis was tested on R\&D subsidies (Feldman and Kelley 2006; Lerner 1999; Meuleman and De Maeseneire 2012) and Government VC (Guerini and Quas 2015), we test it for the first time on PLs. We argue that the receipt of PLs may also reduce moral hazard problems between SMEs and commercial banks. PLs align SMEs and lenders' interests by requiring the lender to commit additional capital.

We test our hypotheses on a sample of 488 firms receiving PLs from a Spanish government agency (ENISA) between 2005 and 2010 and a control group of 719 peers. We find that SMEs receiving PLs have significantly higher financial debt $(+31.5 \%)$, well beyond the value of the loan itself. The effect is driven by firms operating in hightechnology sectors and small firms (i.e., less than 6 million euros of total assets at the moment of the receipt of the PL), which are characterized by higher information asymmetries. In contrast, we do not find a significant effect on younger firms, probably because ENISA-backed firms were all very young at the time the loan was granted (70\% and $85 \%$ of them were, respectively, less than 5 and 10 years old). The certification effect is not significant for firms that had previously received government support and whose quality was arguably already certified by another government agency. On the contrary, we do not find that firms that received VC (also a certifying body) were less affected by the receipt of PLs. One possible explanation for this result is that the information conveyed by VC and the government is not redundant in the eye of commercial banks, provided that it comes from totally different sources. Lastly, the effect of PLs is stronger for companies with fewer tangible assets, i.e. lower values of collateral.

This work contributes to the literature on entrepreneurial finance in several ways. First, by focusing on hybrid financial instruments, which have only recently attracted the interest of policymakers (OECD 2015), we extend the existing literature on the different forms of government support to young and innovative firms (North et al. 2001). Second, we complement the existing evidence on the certification effect of government support towards external investors by studying under which conditions the effect is stronger, thus expanding the study of Meuleman and De Maeseneire (2012). Third, we contribute to the existing evidence on the impact of policy measures undertaken by public authorities to fill the funding gap in SMEs. While other researchers have found that the receipt of government support reduces the financial constraints of award-receiving firms (e.g., Colombo et al. 2013), this work provides more 
details about the mechanisms through which this effect is enhanced. In particular, besides the aforementioned certification effect, we also find that the receipt of PLs allows firms to increase the value of their collateral, which in turn improves access to commercial debt. The certification effect and the collateral effect partially mediate each other.

We believe that this paper also has interesting policy implications. In the struggle to design appropriate schemes to support SMEs (Colombo et al. 2014), policy makers throughout the world have recently directed their attention towards hybrid instruments, which combine debt and equity features (OECD 2015). This paper supports the use of one of these new schemes: PLs. As a policy instrument, PLs are characterized by a lower burden than R\&D subsidies in terms of government spending, which is a concern nowadays to reduce the government deficit, especially in the light of the fact that the benefits of R\&D subsidies do not always cover their costs (Decramer and Vanormelingen 2016). Furthermore, the institution granting the loans does not face as much risk as in the case of pure equity investments. In addition, the potential universe of firms that could take advantage of this instrument is significantly larger than that of VC. From the entrepreneurs' point of view, with PLs SMEs face minimum interest payments until breakeven is reached, and are not affected by internal capital dilution. Moreover, we show that PLs exert a negligible certification effect on low-technology, medium-sized companies with sizeable tangible assets, or in companies that already received support from government institutions. These results may provide guidance to governmental agencies in the selective provision of their loans.

ENISA clearly represents a success story that could be an inspiration for policy makers outside Spain whose objective is to facilitate SMEs' access to external finance. This study shows that ENISA is considered as a reputable certifying agency by private-sector institutions, which value and trust the screening skills of ENISA. ENISA has developed its reputation as a capable screener, especially in the high-technology sector, by being active in the VC industry for more than ten years before turning its interest to quasi-equity instruments. One important caveat for policy makers is, therefore, to build the reputation of the certifying agency, for instance, by relying on a recognized experience and success of an existing institution.

This work presents some limitations that open avenues for future research. While we describe the potential advantages of PLs over R\&D subsidies and government-affiliated VC, future research may offer empirical evidence on whether the peculiarities of PLs effectively result in a higher certification effect of SMEs towards banks than other types of government intervention. This type of study would be especially useful to develop interesting policy 
implications, and is at the very top of our research agenda. Future contributions to the government certification literature towards commercial banks should also test whether the certification effect is stronger for short-term or longterm debt and whether it also has an effect on the cost of debt, rather than on the amount received. Finally, it would be interesting to test to what extent the certification effect is affected by the self-selection condition imposed through the capital increase that recipient firms are required to complete. 


\section{References}

Agostino, M., \& Trivieri, F. (2014). Does Trade Credit Play a Signalling Role? Some Evidence from SMEs Microdata. Small Business Economics, 42(1), 131-151. doi:10.1007/s11187-013-9478-8

Alperovych, Y., Hübner, G., \& Lobet, F. (2015). How does Governmental versus Private Venture Capital Backing Affect a Firm's Efficiency? Evidence from Belgium. Journal of Business Venturing, 30(4), 508-525. doi:10.1016/j.jbusvent.2014.11.001

Bernanke, B. S., Gertler, M., \& Gilchrist, S. (1996). The Financial Accelerator and the Flight to Quality. Review of Economics and Statistics, 78(1), 1-15. doi:10.3386/w4789

Bertoni, F., \& Tykvová, T. (2015). Does Governmental Venture Capital Spur Invention and Innovation? Evidence from Young European Biotech Companies. Research Policy, 44(4), 925-935. doi:10.1016/j.respol.2015.02.002

Bester, H. (1985). Screening vs Rationing in Credit Markets with Imperfect Information. American Economic Review, 75(4), 850-855. http://www.jstor.org/stable/1821362

Binks, M. R., \& Ennew, C. T. (1996). Growing Firms and the Credit Constraint. Small Business Economics, 8(1), $17-$ 25. doi:10.1007/BF00391972

Binks, M. R., Ennew, C. T., \& Reed, G. V. (1992). Information Asymmetries and the Provision of Finance to Small Firms. International Small Business Journal, 11(1), 35-46. doi:10.1177/026624269201100103

Busom, I., Corchuelo, B., \& Martínez-Ros, E. (2014). Tax Incentives... Or Subsidies for Business R\&D? Small Business Economics, 4(3), 571-596. doi:10.1007/s11187-014-9569-1

Carpenter, R. E., \& Petersen, B. C. (2002a). Is the Growth of Small Firms Constrained by Internal Finance? Review of Economics and Statistics, 84(2), 298-309. doi:10.1162/003465302317411541

Carpenter, R. E., \& Petersen, B. C. (2002b). Capital Market Imperfections, High-Tech Investment, and New Equity Financing. Economic Journal, 112(477), F54-F72. doi:10.1111/1468-0297.00683

Chemmanur, T. J., Krishnan, K., \& Nandy, D. K. (2011). How Does Venture Capital Financing Improve Efficiency in Private Firms? A look Beneath the Surface. Review of Financial Studies, 24(617), 4037-4090. doi:10.1093/rfs/hhr096

Colombo, M. G., Croce, A., \& Guerini, M. (2013). The Effect of Public Subsidies on Firms' Investment-Cash Flow Sensitivity: Transient or Persistent? Research Policy, 42(9), 1605-1623. doi:10.1016/j.respol.2013.07.003

Colombo, M. G., Cumming, D. J., \& Vismara, S. (2016). Governmental Venture Capital For Innovative Young Firms. Journal of Technology Transfer, 41(1), 10-24. doi:10.1007/s10961-014-9380-9

Croce, A., Martì Pellon, J., \& Murtinu, S. (2013). The Impact of Venture Capital on the Productivity Growth of European Entrepreneurial Firms: "Screening" or "Value Added" Effect? Journal of Business Venturing, 28(4), 489-510. doi:10.1016/j.jbusvent.2012.06.001

Czarnitzki, D., \& Delanote, J. (2015). R\&D Policies for Young SMEs: Input and Output Effects. Small Business Economics, 45(3), 465-485. doi:10.1007/s11187-015-9661-1

Dalla Pellegrina, L., Frazzoni, S., Rotondi, Z., \& Vezzulli, A. (2016). Does ICT Adoption Improve Access to Credit for Small Enterprises? Small Business Economics, doi:10.1007/S11187-016-9794-X

Decramer, S., \& Vanormelingen, S. (2016). The Effectiveness of Investment Subsidies: Evidence From a Regression Discontinuity Design. Small Business Economics, doi:10.1007/s11187-016-9749-2

Diamond, D. W. (1991). Monitoring and Reputation: The Choice between Bank Loans and Directly Placed Debt. Journal of Political Economy, 99(4), 689-721. doi:10.1086/261775

Eurostat. (2015). Eurostat Indicators on High-Tech Industry and Knowledge - Intensive Services. Annex 3. http://epp.eurostat.ec.europa.eu/cache/ITY_SDDS/Annexes/htec_esms_an3.pdf. Accessed 16 January 2016.

Feldman, M. P., \& Kelley, M. R. (2003). Leveraging Research and Development: Assessing the Impact of the US Advanced Technology Program. Small Business Economics, 20(2), 153-165. doi:10.1023/A:1022264031993

Feldman, M. P., \& Kelley, M. R. (2006). The Ex-Ante Assessment of Knowledge Spillovers: Government R\&D Policy, Economic Incentives and Private Firm Behavior. Research Policy, 35(10), 1509-1521. 
doi:10.1016/j.respol.2006.09.019

Grilli, L., \& Murtinu, S. (2014). Government, Venture Capital and the Growth of European High-tech Entrepreneurial Firms. Research Policy, 43(9), 1523-1543. doi:10.1016/j.respol.2014.04.002

Grilli, L., \& Murtinu, S. (2015). New Technology-Based Firms in Europe: Market Penetration, Public Venture Capital, and Timing of Investment. Industrial and Corporate Change, 24(5), 1109-1148. doi:10.1093/icc/dtu025

Guerini, M., \& Quas, A. (2015). Governmental Venture Capital in Europe: Screening and Certification. Journal of Business Venturing, 31(2), 175-195. doi:10.1016/j.jbusvent.2015.10.001

Hall, B. H. (2002). The Financing of Research and Development. Oxford Review of Economic Policy, 18(1), 35-51. doi:10.1093/oxrep/18.1.35

Heckman, J. J. (1979). Sample Selection Bias as a Specification Error. Econometrica, 47(1), $153-161$. doi:10.2307/1912352

Huergo, E., \& Moreno, L. (2014). National or International Public Funding? Subsidies or Loans? Evaluating the Innovation Impact of R\&D Support Programmes. MPRA paper NO. 54218, 1-35.

Huergo, E., Trenado, M., \& Ubierna, A. (2013). The Impact of Low-Interest Credits on Business R\&D Expenditures: Spanish Firms and CDTI Loans for R\&D projects. MPRA paper No. 44221, 1-57.

Infelise, F. (2014). Supporting Access to Finance by SMEs: Mapping the Initiatives in Five EU countries. Flensburg (GER). https://www.ceps.eu/publications/supporting-access-finance-smes-mapping-initiatives-five-eucountries. Accessed 3 June 2015.

Karhunen, H., \& Huovari, J. (2015). R\&D Subsidies and Productivity in SMEs. Small Business Economics, 45(4), 805-823. doi:10.1007/s11187-015-9658-9

Kleer, R. (2010). Government R\&D Subsidies as a Signal for Private Investors. Research Policy, 39(10), $1361-1374$. doi:10.1016/j.respol.2010.08.001

Kuo, C.-J., Chen, C.-M., \& Sung, C.-H. (2011). Evaluating Guarantee Fees for Loans to Small and Medium-Sized Enterprises. Small Business Economics, 37(2), 205-218. doi:10.1007/s11187-009-9236-0

Lee, P. M., \& Wahal, S. (2004). Grandstanding, Certification and the Underpricing of Venture Capital Backed IPOs. Journal of Financial Economics, 73(2), 375-407. article. doi:10.1016/j.jfineco.2003.09.003

Leleux, B., \& Surlemont, B. (2003). Public versus Private Venture Capital: Seeding or Crowding Out? A Pan-European Analysis. Journal of Business Venturing, 18(1), 81-104. doi:10.1016/S0883-9026(01)00078-7

Lemmon, M. L., Roberts, M. R., \& Zender, J. F. (2008). Back to the Beginning: Persistence and the Cross-Section of Corporate Capital Structure. Journal of Finance, 63(4), 1575-1608. doi:10.1111/j.1540-6261.2008.01369.x

Lerner, J. (1999). The Government as Venture Capitalist: The Long-Run Impact of the SBIR Program. Journal of Business, 72(3), 285-318. article. doi:10.3905/jpe.2000.319960

Lerner, J. (2002). When Bureaucrats Meet Entrepreneurs: The Design of Effective "Public Venture Capital" Programmes. Economic Journal, 112(477), F73-F84. doi:10.1111/1468-0297.00684

Magri, S. (2009). The Financing of Small Innovative Firms: the Italian Case. Economics of Innovation and New Technology, 18(2), 181-204. doi:10.1080/10438590701738016

Meuleman, M., \& De Maeseneire, W. (2012). Do R\&D Subsidies Affect SMEs' Access to External Financing? Research Policy, 41(3), 580-591. doi:10.1016/j.respol.2012.01.001

Michaelas, N., Chittenden, F., \& Poutziouris, P. (1999). Financial Policy and Capital Structure Choice in U.K. SMEs: Empirical Evidence from Company Panel Data. Small Business Economics, 12(2), $113-130$. doi:10.1023/A:1008010724051

Minola, T., Vismara, S., \& Hahn, D. (2016). Screening Model for the Support of Governmental Venture Capital. Journal of Technology Transfer, doi:10.1007/s10961-015-9461-4

Myers, S. C., \& Majluf, N. S. (1984). Corporate Financing and Investment Decisions When Firms Have Information That Investors Do Not Have. Journal of Financial Economics, 13(2), 187-221. doi:10.1016/0304405X(84)90023-0 
North, D., Smallbone, D., \& Vickers, I. (2001). Public Sector Support for Innovating SMEs. Small Business Economics, 16(4), 303-317. doi:10.1023/A:1011164801073

OECD. (2015). New approaches to SME and Entrepreneurial Financing: Broadening the Range of Instruments. http://www.oecd.org/cfe/smes/New-Approaches-SME-full-report.pdf. Accessed 13 January 2016

Pollock, T. G., Chen, G., Jackson, E. M., \& Hambrick, D. C. (2010). How Much Prestige is Enough? Assessing the Value of Multiple Types of High-Status Affiliates for Young Firms. Journal of Business Venturing, 25(1), 6-23. doi:10.1016/j.jbusvent.2009.01.003

Puri, M., \& Zarutskie, R. (2012). On the Life Cycle Dynamics of Venture-Capital- and Non-Venture-Capital-Financed Firms. Journal of Finance, 67(6), 2247-2293.

Sogorb-Mira, F. (2005). How SME Uniqueness Affects Capital Structure: Evidence From a 1994-1998 Spanish Data Panel. Small Business Economics, 25, 447-457. doi:10.1007/s11187-004-6486-8

Sørensen, J. B., \& Stuart, T. E. (2000). Aging, Obsolescence, and Organizational Innovation. Administrative Science Quarterly, 45(1), 81-112. doi:10.2307/2666980

Stiglitz, J. E., \& Weiss, A. (1981). Credit Rationing in Markets with imperfect Information. American Economic Review, 71, 393-409. http://www.jstor.org/stable/1802787

Teece, D. J. (1986). Profiting from Technological Innovation: Implications for Integration, Collaboration, Licensing and Public Policy. Research Policy, 15(6), 285-305. doi:10.1016/0048-7333(86)90027-2

Tirole, J. (2006). The Theory of Corporate Finance. Princeton (NJ): Princeton University Press.

Titman, S., \& Wessels, R. (1988). The Determinants of Capital Structure Choice. Journal of finance, 43(1), 1-19. doi:10.1111/j.1540-6261.1988.tb02585.x

Ueda, M. (2004). Banks versus Venture Capital: Project Evaluation, Screening, and Expropriation. Journal of Finance, 59(2), 601-621. doi:10.1111/j.1540-6261.2004.00643.x

Vander Bauwhede, H., De Meyere, M., \& Van Cauwenberge, P. (2015). Financial Reporting Quality and the Cost of Debt of SMEs. Small Business Economics, 45(1), 149-164. doi:10.1007/s11187-015-9645-1

Vella, F., \& Verbeek, M. (1999). Estimating and Interpreting Models with Endogenous Treatment Effects. Journal of Business \& Economic Statistics, 17(4), 473-478. doi:10.1080/07350015.1999.10524835

Zúñiga Vicente, J., Alonso-Borrego, C., Forcadell, F. J., \& Galàn, J. I. (2014). Assessing the Effect of Public Subsidies on Firm R\&D Investment: A Survey. Journal of Economic Surveys, 28(1), 36-67. doi:10.1111/j.14676419.2012.00738.x 
Tables

Table 1: Universe of ENISA loans belonging to the programs EBT, PYME and JOVENES

\begin{tabular}{|c|c|c|c|c|c|c|c|}
\hline \multicolumn{8}{|c|}{ Panel A. Amount of loans to firms receiving the first loan between 2005 and 2010 (in 1000 Euros) } \\
\hline Program & 2005 & 2006 & 2007 & 2008 & 2009 & 2010 & Total \\
\hline EBT & 5,600 & 12,943 & 10,030 & 16,092 & 17,285 & 17,805 & 79,755 \\
\hline PYME & 3,920 & 6,975 & 11,378 & 15,013 & 22,840 & 65,460 & 125,585 \\
\hline JOVENES & 0 & 0 & 0 & 0 & 0 & 6,597 & 6,597 \\
\hline Total & 9,520 & 19,918 & 21,408 & 31,105 & 40,125 & 89,862 & 211,937 \\
\hline \multicolumn{8}{|c|}{ Panel B. Number of loans to firms receiving the first loan between 2005 and 2010} \\
\hline Program & 2005 & 2006 & 2007 & 2008 & 2009 & 2010 & Total \\
\hline EBT & 22 & 46 & 40 & 65 & 70 & 67 & 310 \\
\hline PYME & 12 & 20 & 31 & 47 & 76 & 211 & 397 \\
\hline JOVENES & 0 & 0 & 0 & 0 & 0 & 160 & 160 \\
\hline Total & 34 & 66 & 71 & 112 & 146 & 438 & 867 \\
\hline \multicolumn{8}{|c|}{ Panel C. Number of firms receiving loans between 2005 and 2010} \\
\hline Program & 2005 & 2006 & 2007 & 2008 & 2009 & 2010 & Total \\
\hline EBT & 22 & 34 & 26 & 42 & 54 & 46 & 224 \\
\hline PYME & 12 & 16 & 23 & 35 & 62 & 163 & 311 \\
\hline JOVENES & 0 & 0 & 0 & 0 & 0 & 159 & 159 \\
\hline Total & 34 & 50 & 49 & 77 & 116 & 368 & 694 \\
\hline
\end{tabular}

Source: ENISA. 
Table 2: Distribution of sample ENISA-backed firms by industry, region and foundation period

\begin{tabular}{lrrrrr}
\hline \hline & No & \multicolumn{2}{c}{ \% } & No & $\%$ \\
& & & & & \\
Industry & & & Region & & \\
$\quad$ Chemicals and materials & 28 & 5.74 & Andalucía & 32 & 6.56 \\
Computers, electronics, equipment & 46 & 9.43 & Aragón & 15 & 3.07 \\
Other low-technology manufacturing & 31 & 6.35 & Asturias & 10 & 2.05 \\
Other high-technology manufacturing & 20 & 4.10 & Baleares & 6 & 1.23 \\
Trade & 46 & 9.43 & Canarias & 1 & 0.20 \\
ICT & 36 & 7.38 & Cantabria & 5 & 1.02 \\
Professional services & 57 & 11.68 & Castilla La Mancha & 10 & 2.05 \\
Personal services & 33 & 6.76 & Castilla León & 10 & 2.05 \\
Software & 90 & 18.44 & Cataluña & 154 & 31.56 \\
R\&D and engineering & 48 & 9.84 & Comunidad Valenciana & 35 & 7.17 \\
Other low tech services & 28 & 5.74 & Extremadura & 15 & 3.07 \\
Other high tech services & 25 & 5.12 & Galicia & 12 & 2.46 \\
Total & 488 & 100.00 & La Rioja & 2 & 0.41 \\
Foundation period & & & Madrid & 118 & 24.18 \\
Founded before 2001 & 133 & 27.25 & Murcia & 10 & 2.05 \\
Founded between 2001 and 2004 & 117 & 23.98 & Navarra & 17 & 3.48 \\
Founded between 2005 and 2007 & 127 & 26.02 & Pais Vasco & 36 & 7.38 \\
Founded after 2007 & 111 & 22.75 & Total & 488 & 100.00 \\
Total & 488 & 100.00 & & & \\
\hline \hline
\end{tabular}

Source: Based on data extracted from Orbis. 
Table 3: Firm characteristics in the year of the receipt of the first participative loan

\begin{tabular}{|c|c|c|c|c|c|c|c|c|c|}
\hline Variable & $\mathrm{n}$ & & Mean & Std. Dev. & Min & 25th pct & Median & 75th pct & Max \\
\hline $\log$ TotalAssets $_{\text {timeofPL }}{ }_{i}$ & & 488 & 6.722 & 2.251 & 0.000 & 5.872 & 6.977 & 8.048 & 12.206 \\
\hline$A e^{t i m e o f P L_{i}}$ & & 488 & 6.975 & 8.906 & 0.000 & 2.000 & 4.000 & 9.000 & 57.000 \\
\hline HighTech $_{i}$ & & 488 & 0.377 & 0.485 & 0.000 & 0.000 & 0.000 & 1.000 & 1.000 \\
\hline PublicSupport ${ }^{\text {timeofPL }}{ }_{i}$ & & 488 & 0.061 & 0.240 & 0.000 & 0.000 & 0.000 & 0.000 & 1.000 \\
\hline$V C^{\text {timeofPL }}{ }_{i}$ & & 488 & 0.260 & 0.439 & 0.000 & 0.000 & 0.000 & 1.000 & 1.000 \\
\hline
\end{tabular}

logTotalAssets $^{\text {timeofPL }}{ }_{i}$ : Logarithm of the book value of total assets in th EUR one year before the receipt of the first PL. Age ${ }^{\text {timeofPL }}{ }_{i}$ : Years since the firm was established at the time of the receipt of the first PL. $V C^{\text {timeofPL }}$ : Dummy equal to 1 if a company received its first VC round before the receipt of the first PL. PublicSupport ${ }^{\text {timeofP }}{ }_{i \text { : }}$ Dummy equal to 1 if a company received its first subsidized loan from either CDTI or ACCIO before the receipt of the first PL. 
Table 4: Variable description

\begin{tabular}{lrrrrrrr}
\hline \hline Variable & $\mathbf{N}$ & $\mathbf{n}$ & Mean & Median & Std. Dev. & Min & Max \\
\hline logDebt $_{i, t}$ & 1,207 & 6,919 & 6.317 & 6.395 & 2.345 & 0.000 & 16.811 \\
PL $_{\mathrm{i}, \mathrm{t}}$ & 1,207 & 6,919 & 0.248 & 0.000 & 0.432 & 0.000 & 1.000 \\
logTotalAssets $_{i, t-1}$ & 1,207 & 6,919 & 7.626 & 7.513 & 1.769 & 0.000 & 17.526 \\
TotalAssetGrowth $_{i, t-1}$ & 1,207 & 6,919 & 0.607 & 0.148 & 1.484 & -6.631 & 11.641 \\
Tangibles $_{i, t}$ & 1,207 & 6,919 & 0.217 & 0.115 & 0.242 & 0.000 & 0.930 \\
Profitability $_{i, t-1}$ & 1,207 & 6,919 & 3.790 & 0.060 & 18.684 & -17.528 & 353.681 \\
Liquidity $_{i,-1}$ & 1,207 & 6,919 & 0.155 & 0.078 & 0.189 & 0.000 & 0.931 \\
logEquity $_{i, t-1}$ & 1,207 & 6,919 & 4.982 & 5.091 & 2.341 & 0.000 & 16.141 \\
Age $_{i, t}$ & 1,207 & 6,919 & 9.875 & 7.000 & 9.348 & 1.000 & 59.000 \\
PublicSupport $_{i, t-1}$ & 1,207 & 6,919 & 0.053 & 0.000 & 0.225 & 0.000 & 1.000 \\
VCC $_{i, t-1}$ & 1,207 & 6,919 & 0.267 & 0.000 & 0.443 & 0.000 & 1.000 \\
\hline \hline
\end{tabular}

logDebt $t_{i, t}$ Logarithm of the amount of financial debt in th EUR, reduced by the amount of the PL the company owes to the government. $P L_{i, t}$ : Dummy variable equal to 1 in the year in which a company received its first PL and in all the following years, and 0 otherwise. logTotalAssets i,t- $_{\text {: }}$ Logarithm of the book value of total assets in $\mathrm{t}$ in th EUR, lagged by one year. TotalAssetGrowth ${ }_{i, t-1}$ : Difference between the logarithm of the book value of total assets in $t$ in th EUR, and the logarithm of the book value of total assets in t-1 in th EUR, lagged by one year. Tangibles $s_{i, t-1}$ : book value of tangible fixed assets divided by total assets, lagged by one year. Profitability $y_{i,-1}$ : Earnings before interest, taxes, depreciation and amortization over total assets, lagged by one year. $\log E_{\text {equity }}, t,-1$ is the logarithm of the book value of equity in the previous year. Liquidity ${ }_{i, t-1}$ : book value of the cash divided by total assets, lagged by one year. Age $e_{i, t}$ : Years since the firm was established. $V C_{i, t}$ : Dummy equal to 1 in the year in which a company received its first VC round and in all the following years, and 0 otherwise. PublicSupport ${ }_{i, t}$ : Dummy equal to 1 in the year in which a firm received its first subsidized loan from either CDTI or ACCIO and in all the following years, and 0 otherwise. 
Table 5: Pairwise correlation matrix of variables

\begin{tabular}{|c|c|c|c|c|c|c|c|c|c|c|c|c|}
\hline & Variable & 1 & 2 & 3 & 4 & 5 & 6 & 7 & 8 & 9 & 10 & 11 \\
\hline 1 & $\log D e b t_{i, t}$ & 1.00 & & & & & & & & & & \\
\hline 2 & $P L_{\mathrm{i}, \mathrm{t}}$ & 0.09 & 1.00 & & & & & & & & & \\
\hline 3 & logTotalAssets $_{i, t-1}$ & 0.76 & 0.07 & 1.00 & & & & & & & & \\
\hline 4 & TotalAssetGrowth $_{i,-1}$ & -0.15 & -0.01 & -0.22 & 1.00 & & & & & & & \\
\hline 5 & Tangibles $_{i, t}$ & 0.22 & -0.08 & 0.13 & -0.04 & 1.00 & & & & & & \\
\hline 6 & Profitability $_{i, t-1}$ & 0.05 & 0.08 & 0.06 & -0.08 & 0.02 & 1.00 & & & & & \\
\hline 7 & $\log _{E^{\prime}}$ ity $_{i, t-1}$ & -0.28 & -0.01 & -0.29 & 0.23 & -0.26 & -0.01 & 1.00 & & & & \\
\hline 8 & Liquidity $_{i, t-1}$ & 0.54 & 0.11 & 0.68 & -0.15 & 0.17 & 0.16 & -0.21 & 1.00 & & & \\
\hline 9 & $A g e_{i, t}$ & $\mathbf{0 . 3 3}$ & -0.03 & 0.46 & -0.31 & 0.08 & 0.04 & -0.19 & 0.30 & 1.00 & & \\
\hline 10 & PublicSupport $_{i, t-1}$ & -0.01 & 0.08 & -0.10 & -0.01 & -0.12 & 0.01 & 0.07 & -0.02 & -0.12 & 1.00 & \\
\hline & $V C_{i, t-1}$ & 0.26 & 0.15 & 0.29 & -0.07 & 0.04 & 0.06 & -0.06 & 0.29 & 0.01 & -0.10 & 1.00 \\
\hline
\end{tabular}

The correlation matrix is based on 6,919 observations. The description of variables is available in Table 4. Bold correlation coefficients are significant at least with $\mathrm{p}<0.10$. 
Table 6: Analysis of firms' financial debt: hypotheses testing

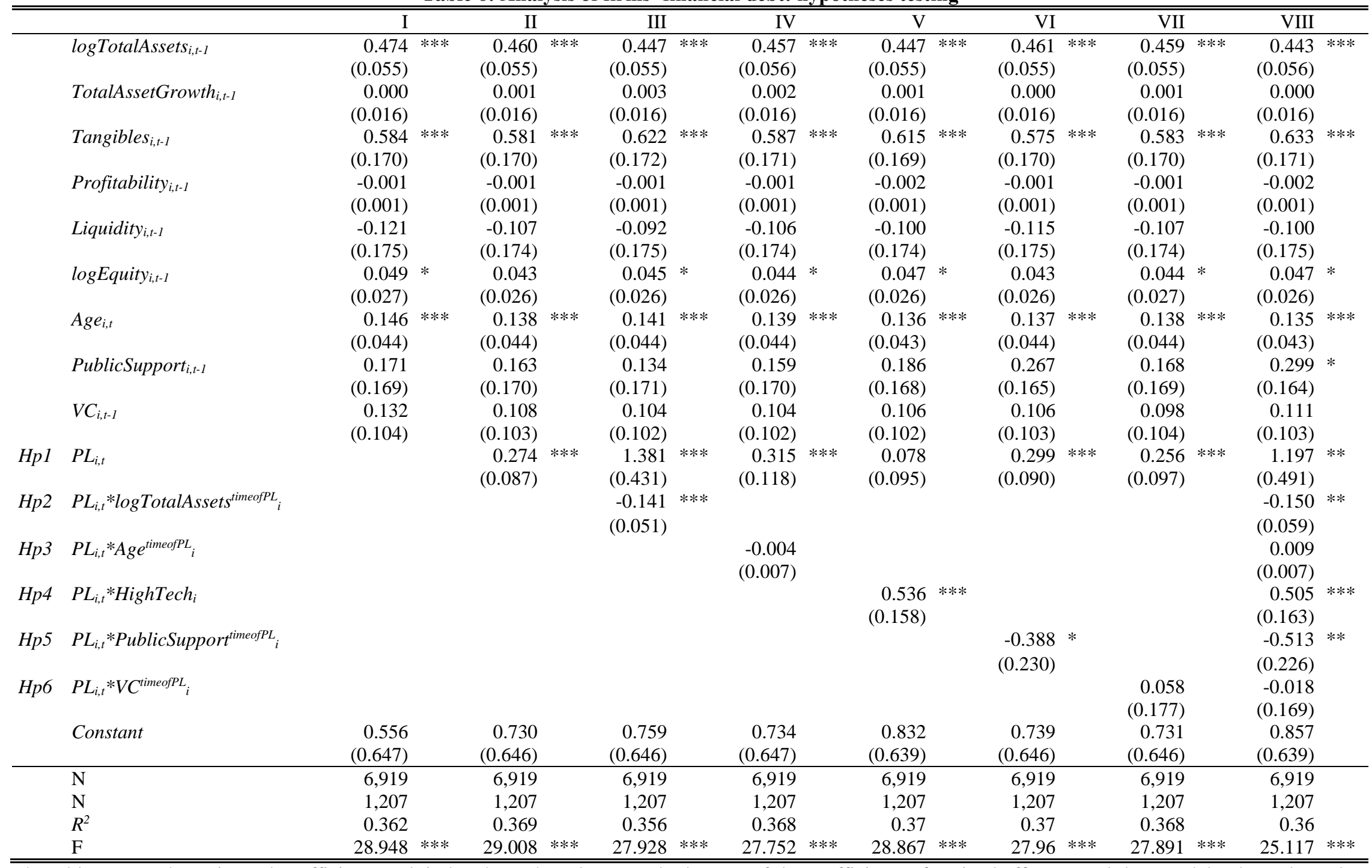

The table reports the estimated coefficients and, in brackets, the robust standard errors of the coefficients of a Fixed effects panel data model, whose dependent variable is $\log \mathrm{Debt}_{i, t}$. The Hausman test for the appropriateness of the Random-Effects estimator was rejected with $\chi^{2}(20)=296.99$, significant at $1 \%$ The description of variables is available in Table 4 . Year dummies are included in the model but omitted in the table. Significance: $* \mathrm{p}<0.10 ; * * \mathrm{p}<0.05 ; * * * \mathrm{p}<0.01$. 
Table 7: Analysis of firms' financial debt: robustness checks

\begin{tabular}{|c|c|c|c|c|c|c|c|}
\hline & Model & $\begin{array}{l}\text { I } \\
\text { Probit mo } \\
\text { the receipt }\end{array}$ & $\begin{array}{l}\text { lon } \\
\text { f PLs }\end{array}$ & $\begin{array}{r}\text { II } \\
\text { RC: PL } \\
\text { endogene }\end{array}$ & & $\begin{array}{r}\text { III } \\
\text { RC: effec } \\
\text { collater }\end{array}$ & \\
\hline & logTotalAssets $_{i, t-1}$ & -0.091 & $* * *$ & 0.442 & $* * *$ & 0.445 & $* * *$ \\
\hline & & $(0.032)$ & & $(0.049)$ & & $(0.055)$ & \\
\hline & TotalAssetGrowth ${ }_{i, t-1}$ & 0.064 & $* * *$ & 0.001 & & 0.000 & \\
\hline & & $(0.020)$ & & $(0.017)$ & & $(0.016)$ & \\
\hline & Tangibles $_{i, t-1}$ & -0.556 & $* * *$ & 0.631 & $* * *$ & 0.761 & $* * *$ \\
\hline & & $(0.189)$ & & $(0.192)$ & & $(0.175)$ & \\
\hline & Profitability $_{i, t-1}$ & -0.079 & $*$ & -0.002 & $*$ & -0.002 & \\
\hline & & $(0.040)$ & & $(0.001)$ & & $(0.001)$ & \\
\hline & Liquidity $_{i, t-1}$ & -0.262 & & -0.100 & & -0.106 & \\
\hline & & $(0.193)$ & & $(0.164)$ & & $(0.174)$ & \\
\hline & $\log _{\text {Equity }}{ }_{i, t-1}$ & 0.115 & $* * *$ & 0.047 & & 0.047 & $*$ \\
\hline & & $(0.028)$ & & $(0.032)$ & & $(0.026)$ & \\
\hline & $A g e_{i, t}$ & -0.001 & & 0.135 & $* * *$ & 0.134 & $* * *$ \\
\hline & & $(0.005)$ & & $(0.047)$ & & $(0.043)$ & \\
\hline & PublicSupport $_{i, t-1}$ & 0.118 & & 0.300 & $*$ & 0.283 & $*$ \\
\hline & & $(0.166)$ & & $(0.156)$ & & $(0.165)$ & \\
\hline & $V C_{i, t-1}$ & 0.253 & $* *$ & 0.111 & & 0.104 & \\
\hline & & $(0.100)$ & & $(0.101)$ & & $(0.103)$ & \\
\hline & ENISAavailability $_{i, t}$ & 0.013 & $*$ & & & & \\
\hline & & $(0.007)$ & & & & & \\
\hline & $\lambda_{\mathrm{PL}}$ & & & 0.009 & & & \\
\hline & & & & $(0.018)$ & & & \\
\hline & $P L_{i, t} *$ Tangibles $_{i, t-1}$ & & & & & -0.725 & $* *$ \\
\hline & & & & & & $(0.305)$ & \\
\hline Hpl & $P L_{i, t}$ & & & 1.181 & $* *$ & 1.219 & $* *$ \\
\hline & & & & $(0.463)$ & & $(0.490)$ & \\
\hline$H p 2$ & $P L_{i, t}{ }^{*} \log$ TotalAssets $^{\text {timeof } P L_{i}}$ & & & -0.150 & $* * *$ & -0.132 & $* *$ \\
\hline & & & & $(0.057)$ & & $(0.060)$ & \\
\hline Hp3 & $P L_{i, t} * A g e^{\text {timeof } P L_{i}}$ & & & 0.009 & & 0.010 & \\
\hline & & & & $(0.006)$ & & $(0.007)$ & \\
\hline Hp4 & $P L_{i, t} * H_{i g h T e c h}$ & & & 0.504 & $* * *$ & 0.414 & $* * *$ \\
\hline & & & & $(0.168)$ & & $(0.158)$ & \\
\hline Hp5 & $P L_{i, t}{ }^{*}$ PublicSupport ${ }^{\text {timeof } P L_{i}}$ & & & -0.513 & $* * *$ & -0.555 & $* *$ \\
\hline & & & & $(0.188)$ & & $(0.222)$ & \\
\hline Hp6 & $P L_{i, t} * V C^{\text {timeof } P L_{i}}$ & & & -0.018 & & -0.012 & \\
\hline & & & & $(0.176)$ & & $(0.168)$ & \\
\hline & Constant & -0.622 & $* *$ & 0.856 & & 0.832 & \\
\hline & & $(0.312)$ & & $(0.623)$ & & $(0.637)$ & \\
\hline & $\mathrm{N}$ & 3,942 & & 6,919 & & 6,919 & \\
\hline & $\mathrm{N}$ & 1,096 & & 1,207 & & 1,207 & \\
\hline & $\mathrm{R}^{2}$ & & & 0.359 & & 0.362 & \\
\hline & $\chi^{2}$ & 101.058 & $* * *$ & 1166.41 & $* * *$ & 24.386 & $* * *$ \\
\hline & $\mathrm{F}$ & & & & & -9872.25 & \\
\hline & $\mathrm{Ll}$ & -1214.4 & & -9877.83 & & 6,919 & \\
\hline
\end{tabular}

The table reports the estimated coefficients and, in brackets, the standard errors of several models. Column I shows a Probit model with random effects modeling the receipt of the first PL. Observations after the first receipt of the PL are excluded. Columns II and III show fixed effects estimators for panel data. The dependent variable is $l o g D e b t_{i, t,}$. In Column II, standard errors are bootstrapped. Industry, region and year dummies are included. ENISAavailability ${ }_{i, t}$ represents the total amount of PLs granted by ENISA by year and province, expressed in million Euros. $\lambda_{\mathrm{PL}}$ is an endogeneity correction term based on the Inverse Mills Ratio. The description of the remaining variables is available in Table 4. Significance: $* \mathrm{p}<0.10 ; * * \mathrm{p}<0.05 ; * * * \mathrm{p}<0.01$. 


\section{Appendix}

Table A1: Analysis of firms' financial debt: placebo test

\begin{tabular}{|c|c|c|}
\hline & $\mathrm{I}$ & \\
\hline $\log$ TotalAssets $_{i, t-1}$ & $\begin{array}{r}1.025 \\
(0.040)\end{array}$ & $* * *$ \\
\hline TotalAssetGrowth $_{i, t-1}$ & $\begin{array}{r}0.070 \\
(0.037)\end{array}$ & $*$ \\
\hline Tangibles $_{i, t-1}$ & $\begin{array}{r}1.410 \\
(0.225)\end{array}$ & $* * *$ \\
\hline Profitability $_{i, t-1}$ & $\begin{array}{r}0.001 \\
(0.007)\end{array}$ & \\
\hline Liquidity $_{i, t-1}$ & $\begin{array}{r}-0.223 \\
(0.273)\end{array}$ & \\
\hline $\log _{\text {Equity }}$ i,t-1 & $\begin{array}{r}-0.036 \\
(0.030)\end{array}$ & \\
\hline$A g e_{i, t}$ & $\begin{array}{r}-0.009 \\
(0.006)\end{array}$ & \\
\hline PublicSupport $_{i, t}$ & $\begin{array}{r}1.753 \\
(0.239)\end{array}$ & $* * *$ \\
\hline Venture Capital $_{i, t}$ & $\begin{array}{r}0.363 \\
(0.122)\end{array}$ & $* * *$ \\
\hline ENISA-backed $_{\mathrm{i}}$ & $\begin{array}{r}0.148 \\
(0.147)\end{array}$ & \\
\hline Constant & $\begin{array}{r}-0.678 \\
(1.804) \\
\end{array}$ & \\
\hline $\mathrm{N}$ & 5206 & \\
\hline $\mathrm{N}$ & 1055 & \\
\hline$R^{2}$ & 0.561 & \\
\hline $\mathrm{F}$ & 39.822 & $* * *$ \\
\hline LogLikelihood & -1768.44 & \\
\hline
\end{tabular}

The table reports the estimated coefficients and, in brackets, the robust standard error of the coefficients of a Between Effects model whose dependent variable is $\log D e b t_{i, t}$. Observations after the receipt of the participative loan are excluded. Year, industry and region dummies are included in the model but omitted in the table. The dummy ENISAbacked $_{\mathrm{i}}$ is equal to 1 for ENISA-backed firms. The description of the remaining variables is available in Table 4. Significance: * $\mathrm{p}<0.10$; ** $\mathrm{p}<0.05$; *** $\mathrm{p}<0.01$. 